\title{
EFL Teachers' Challenges in Preparing Young Learners for Cambridge Speaking Tests in Language Centers in the Mekong Delta
}

\author{
Ly Huong Thi Nguyen, Mai Xuan Le \\ Can Tho University, Vietnam
}

\begin{abstract}
This study investigates the challenges that EFL teachers encounter in preparing young learners for Cambridge speaking tests in some language centers in the Mekong Delta. 53 EFL teachers from six language centers in some cities and towns across the Mekong Delta participated in the study. They answered a 25-item questionnaire on seven main difficulties faced by EFL teachers in preparing young learners for Cambridge speaking tests. The findings showed that apart from external challenges such as large class sizes, time pressure as well as a lack of teaching resources and equipment, EFL teachers are challenged by their level of English proficiency and teaching methodology. Therefore, most teachers expect to participate in training courses about how to design and implement effective tasks to motivate young learners' engagement in oral English activities. The implications of these EFL teachers' concerns are for the administrators of language centers such as offering their teaching staff more training courses in addition to teaching materials and facilities for better preparing young learners for the Cambridge speaking tests.
\end{abstract}

Keywords: Cambridge speaking tests, challenges, EFL teachers, language centers, Mekong Delta, young learners.

\section{INTRODUCTION}

To meet the demand for English in the society and the world, most Vietnamese parents nowadays want their children to learn English and to assure that their children achieve a good result of communication. However, English language teaching in some public schools or language centers might primarily focus on grammar, writing and reading skills rather than on speaking and listening skills. They forget that one of the most important purposes of learning a foreign language is to communicate orally, especially for young learners who find it difficult to master reading and writing skills at the early age. The importance of speaking skill is stressed in almost all international English exams in general and Cambridge exams for children in particular such as Starters, Movers, and Flyers tests. Therefore, EFL teachers should spend more time investing in training speaking strategies to assist their young learners in achieving high scores in these Cambridge exams. In order to better support EFL teachers in preparing their young learners to obtain more successes in Cambridge tests, particularly in speaking and in the Mekong Delta, Vietnam, the teachers' challenges or difficulties in practice need investigating. Consequently, this study was conducted to figure out the findings for the driving question, "What are EFL teachers' challenges in preparing young learners for Cambridge speaking test?"

\section{A. Introduction to Cambridge speaking test}

\section{LITERATURE REVIEW}

The speaking test of Cambridge usually has 5 parts. The Cambridge speaking test is conducted face-to-face between one examiner and one candidate that lasts approximately 4 minutes. The mark for the Speaking test is valued based on ratings for interactive listening ability, production of words and phrases, and pronunciation. For 
DOI: $\underline{10.51386 / 25815946 / i j s m s-v 4 i 4 p 131}$

Volume: 4 Issue: 4

July to August 2021

https://www.ijssmsjournal.org

example, in the Speaking test for Starters, in part 1, beginning the speaking test is the greeting between the examiner and the candidate and the examiner asks the child's name. The examiner continues to show what is required and then asks the child to point to some objects on the scene picture. In part 2, the examiner requires the candidate to point to three object cards and instruct the child to place them in various locations on the scene picture. In part 3, the examiner asks the candidate some questions about the scene picture. In part 4 , the examiner also asks the candidate some questions about four object cards.Inpart 5, the examiner asks the candidate some personal questions on topics such as age, family, school and friends.

\section{B. Definition of young learners}

The definition of young learners is children between the ages of about 5 years old to 12 years old (Rixon, 1999), but according to Lynne Cameron; young learners are those under 14 years old. Moreover, the definition of young learners is mainly based on the years spent in the primary or elementary stages of formal education before the transition to secondary school. This is why the ages of the young learners could be varied from one country to the others.In this study, young learners was mentioned that are children between the ages of 5 years old to 14 years old learning at language centers in the Mekong Delta. Hence, young learners have their own special characteristics that differentiate them from adult learners. They should be known and understood by the teachers to improve their quality of teaching and learning process. In relation to this, Halliwel (1992) clarifies some of the characteristics of children as follows:

1. Children are already very good in interpreting meaning without necessarily understanding the individual word.

2. Children already have great skill in using limited language creativity.

3. Children frequently learn indirectly rather than directly.

4. Children take good pleasure in finding and creating fun in what they do.

5. Children have a ready imagination, children words are full of imagination and fantasy,and it is more than simply a matter of enjoyment.

\section{The importance of speaking}

Among the four key language skills, speaking is one of the most important skill required for effective communication (Zaremba, 2006) since "people who know a language are referred to as 'speaker' of the language as if speaking included all other kinds of knowing" (Ur, 2000, p.12). Speaking fulfills students' needs for communicating effectively with others in learning the target language. Speaking is a productive skill, because the people produce language by speaking. Speaking is one of an observable skills in language skills, (Nashruddin, 2012: 77). Then, Brown (2004: 140) states that "Speaking skill can be directly and empirically observed. Those observations are invariably colored by the accuracy and effectiveness of a test-taker's listening skill, which necessarily compromises the reliability and validity of an oral production tests".

In teaching and learning English, speaking is compared to writing which is considered as a productive skill, and opposed to the receptive skills of reading and listening. Additionally, Le (2019) stated that speaking seems to be the most important and the closest to the goal of language teaching: communicative competence. In English speaking classrooms, speaking not only plays an important role in achieving communicative competence but also is used as a tool for students to participate actively in pair or group activities or in the classroom discussions. Young learners acquire English-speaking ability to communicate easily and effectively with teachers or classmates in English speaking classrooms.

There are several studies similar to the research topic. One of them is the study by Copland, Garton and Burns (2014) about challenges faced by teachers of primary English both globally, across the total number of countries involved in the study, and more locally, in five of these countries, namely Colombia, Italy, South Korea, Tanzania and the UAE located in different continents. These researchers also conducted another study (2014) about global practices in teaching English to young learners. They wanted to discover what policy documents inform TEYL practices around the world, better understand teachers' perceptions of their roles and responsibilities, including the challenges they face and identify how solutions may resonate globally. In thesestudies, the researchers 
DOI: $\underline{10.51386 / 25815946 / i j s m s-v 4 i 4 p 131}$

Volume: 4 Issue: 4

July to August 2021

https://www.ijsmsjournal.org

indicated some challenges that EFL teachers faced such as lack of training, lack of knowledge, lack of resources, class size, time pressure and the level of English. Besides, EFL teachers also had the difficulties in facilities and equipment, classroom context as well as in learners' inhibition that would be investigated in the current study.Especially, it seems that there have been few studies conducted in identifying challenges that the teachers encounter when they prepare young learners for Cambridge speaking tests, particularly in the Mekong Delta.

\section{METHODOLOGY}

In order to investigate EFL teachers' challenges in preparing young learners for Cambridge speaking tests, a quantitative method design was used in this study. For the quantitative approach, the questionnaire was adapted from Copland, Garton, and Burns(2014)EFLTeacher Questionnaire. The questionnaire was designed in English applying the five Likert-scale from strongly disagree to strong agree including two sections. The first section focuses on EFL teachers' demographic information regarding gender, age, and years of teaching experience and workplace. The second section is EFL teachers' challenges in preparing Cambridge speaking tests to young learners consisting of seven clusters with twenty five items.

To carry out the study, the questionnaires were first delivered to 13 teachers teaching in some language centers for piloting. Then, the completed questionnaires with 43 items were sent to 53 teachers teaching in most language centers in $8 \mathrm{small} / \mathrm{big}$ cities and towns in the Mekong Delta, Viet Nam. The questionnaire aimed to explore the information about their personal understanding and opinions about the challenges in preparing young learners for Cambridge speaking tests. The questionnaires would be transferred to the participants by email because of a lack of time and geographic distance. And the respondents just took from 15 to 20 minutes to implement and returned quickly. After two weeks, the questionnaires were recollected and continued to conduct the next steps namely data analysis. Then, the collective data was entered into Statistical Package for the Social Science (SPSS) software version 20.0 to analyze. The participants' information is summarized in table I below.

TableI:

THE NUMBER OF TEACHERS BASED ON GENDER, AGE AND YEARS OF TEACHING EXPERIENCE

\begin{tabular}{|c|c|c|c|c|c|c|c|c|c|}
\hline & \multicolumn{2}{|c|}{ Gender } & \multicolumn{4}{|c|}{ Age } & \multicolumn{3}{|c|}{ Years of teaching experience } \\
\hline & Male & Female & $22-25$ & $26-30$ & $31-35$ & Over 35 & $<$ 5years & 5-10years & 11-15years \\
\hline Number & 21 & 32 & 17 & 26 & 7 & 3 & 27 & 19 & 7 \\
\hline
\end{tabular}

In term of questionnaire, table 3.1 showed that 32 females $(60.4 \%)$ and 21 males (39.6\%). There was an unequal distribution of gender among teachers. Among 53 teachers, 17 of them from 22 to 25 years old (32.1\%), 26 teachers from 26 to 30 years old (49.1\%), 7 teachers from 31 to 35 years old (13.2\%) and 3 teachers over 35 years old (5.7\%).Regarding their teaching experience, twenty seven $(50.9 \%)$ of the teachers had under five years experienced in teaching English, nineteen (35.8\%) of the teachers had from five to ten years experienced in teaching English and seven (13.2\%) of the teachers had from eleven to fifteen experienced in teaching English. 
DOI: $\underline{10.51386 / 25815946 / i j s m s-v 4 i 4 p 131}$

Volume: 4 Issue: 4

July to August 2021

https://www.ijsmsjournal.org

EFL teachers ticked their answers to each item in a five-degree scale from strongly disagree to strong agree. The data obtained from the questionnaire were subjected to the Statistics Package for the Social Science (SPSS) for the data analysis. The scale test was run to test the reliability of the questionnaires. The results of the scale test revealed that the reliability coefficient for pilot was high enough $(\boldsymbol{\alpha}=. \mathbf{7 4 9})$. Therefore, the questionnaire was reliable for data collection.

\section{FINDINGS}

After analyzing the data from the questionnaire, EFL teachers' challenges in preparing young learners for Cambridge speaking tests were found.

\section{A. EFL teachers' challenges in preparing Cambridge speaking tests to young learners}

The findings reveal that all EFL teachers in this study face several challengesin preparing young learners for Cambridge speaking tests.

Descriptive Statistics Test and One Sample T Test were run to analyze EFL teachers' challenges in preparing Cambridge speaking tests to young learners. The Descriptive Statistics test first conducted to figure out the mean score (Min), maximum score (Max), mean score (M) and standard deviation (SD)of encountering the 25 challenges of 53 EFL teachers. The table II below displays the results of the Descriptive Statistics Test.

Table II:

THE MEAN SCORE OF EFL TEACHERS' CHALLENGES

\begin{tabular}{lccccc} 
Variable & N & Min. & Max. & Mean & SD \\
\hline EFL teachers' challenges & 53 & 1.80 & 3.56 & 3.01 & .35
\end{tabular}

From table II, it can be seen that the mean score of EFL teachers' challenges was 3.01( $\mathrm{M}=3.01)$. Next, Onesample T Test was administrated to evaluate whether there was a difference between the level of EFL teachers' challenges $(\mathrm{M}=3.01$ at a medium level) and the test value of 3.5, the accepted mean score for high challenges. The result showed that a significant difference between the sample mean $(\mathrm{M}=3.01, \mathrm{SD}=.35)$ and the test value $(\mathrm{M}=3.5)$ was observed $(\mathrm{t}=-10.01$, $\mathrm{df}=52, \mathrm{p}=.00<.05)$. It can be inferred that EFL teachers' challenges facing were moderately challenges. In other words, EFL teachers did not think that these challenges strongly affected their preparing Cambridge speaking tests process.

25 items aimed to find out EFL teachers' challenges in preparing process with seven clusters including (1) teaching methodology, (2) time pressure, (3) facilities and equipment, (4) materials and resources, (5) classroom context, (6) teacher's level of English proficiency, (7) learners' inhibition. The Descriptive Statistics test was used to evaluate the mean scores of each cluster. The table below shows the results of this test.

Table III:

THE MEAN SCORE OF 7 SLUSTERS OF EFL TEACHERS' CHALLENGES

\begin{tabular}{lccccc}
\hline Cluster & N & Minimum & Maximum & Mean & Std. Deviation \\
\hline Teaching methodology & 53 & 1.00 & 3.25 & 2.39 & .45 \\
Time pressure & 53 & 1.00 & 5.00 & 3.39 & 1.19 \\
Facilities and equipment & 53 & 1.00 & 5.00 & 3.85 & 1.00 \\
\hline
\end{tabular}


DOI: $\underline{10.51386 / 25815946 / i j s m s-v 4 i 4 p 131}$

Volume: 4 Issue: 4

July to August 2021

https://www.ijjsmsjournal.org

\begin{tabular}{lccccc}
\hline Materials and resources & 53 & 1.00 & 5.00 & 3.58 & 1.26 \\
Classroom context & 53 & 2.20 & 4.60 & 3.74 & .56 \\
Teacher's level of English proficiency & 53 & 1.43 & 3.86 & 2.80 & .50 \\
Learners' inhibition. & 53 & 1.60 & 3.80 & 2.54 & .51 \\
\hline
\end{tabular}

As can be seen fromtableIII, among seven aspects of challenges, EFL teachers wanted to emphasis the challenge of facilities and equipment more than classroom context, materials and resources, time pressure, teaching methodology, teacher's level of English proficiency, learners' inhibition. The mean score of facilities and equipment $(M=3.85)$ is higher than that of classroom context $(M=3.74)$, materials and resources $(M=3.58)$, time pressure $(M=$ 3.39), teacher's level of English proficiency $(M=2.80)$, learners' inhibition $(M=2.54)$, and teaching methodology $(M=2.39)$. This reveals that EFL teachers faced the challenge of facilities and equipment most and teaching methodology least in preparing Cambridge speaking tests for young learners.

1. Differences in EFL teachers' challenges in preparing young learners for Cambridge speaking tests by years of teaching experience

An Independent Sample $\mathrm{T}$ test was run to check the difference in teachers' challenges in preparing Cambridge speaking tests among teachers having under 5 years, from 5 to 10 years and from 11 to 15 years of teaching experience.

The results in table IV below showed the mean score of three groups of teachers' challenges.

Table IV:

\section{INDEPENDENT SAMPLE T TEST OF MEAN SCORE OF EFL TEACHERS' BY YEARS OF TEACHING EXPERIENCE}

\begin{tabular}{lcccc}
\hline Variables & & $<\mathbf{5}$ years & $\mathbf{5}-\mathbf{1 0}$ years & $\mathbf{1 1 - 1 5}$ years \\
\hline $\begin{array}{l}\text { EFL teachers' } \\
\text { challenges }\end{array}$ & $\mathbf{N}$ & 26 & 22 & 5 \\
& Mean & 2.99 & 3.07 & 2.85 \\
& SD & .06 & .07 & .26 \\
\hline
\end{tabular}

As can be seen from Table IV, EFL teachers having from 5 to 10 years of teaching faced challenges in the highest degree $(M=3.07)$, followed by teachers having less than 5 years of teaching experience $(M=2.99)$, while teachers having from 11 to 15 years of teaching experience had the lowest degree in challenges $(\mathrm{M}=2.85)$. The results indicated that EFL teachers' challenges compared EFL teachers teaching less than 5 years with those teaching from 5 to 10 years and with those having from 11 to 15 years of teaching was not different $(\mathrm{t}=-.90, \mathrm{p}=.24$, $\mathrm{t}=.72, \mathrm{p}=.47)$. Moreover, there was not also significant difference between teachers teaching from 5 to 10 years and teachers having from 11 to 15 years of teaching $(\mathrm{t}=1.19, \mathrm{p}=.10)$. Consequently, EFL teachers prepare Cambridge speaking tests at three degrees of teaching experience faced challenges at the same level. In other word, all EFL teachers at different degrees of teaching experience also had the same challenges in preparing young learners for Cambridge speaking tests.

\section{Differences in EFL teachers' challenges in preparing young learners for Cambridge speaking tests by gender}

An Independent Sample $T$ test was run to check the difference in challenges between female and male teachers in preparing young learners for Cambridge speaking tests. 
Table V:

INDEPENDENT SAMPLE T TEST OF MEAN SCORE OF EFL TEACHERS' BY GENDER

\begin{tabular}{lccc}
\hline Variables & & Male & Female \\
\hline $\begin{array}{l}\text { EFL teachers' } \\
\text { challenges }\end{array}$ & $\mathbf{N}$ & 27 & 26 \\
& Mean & 2.97 & 3.04 \\
& SD & .06 & .07 \\
\hline
\end{tabular}

Noticeably, no difference was seen in the challenges between female and male teachers from the results of Independent Sample $\mathrm{T}$ test run on the mean scores of the two groups of teachers' challenges about this variable did not prove any difference $(\mathrm{t}=-.71, \mathrm{p}=.47)($ table $\mathrm{V})$. It means that female and male teachers faced challenges at the same level.

\section{Differences in EFL teachers' challenges in preparing young learners for Cambridge speaking tests by teaching areas}

An Independent Sample T test was run to check whether there was difference among EFL teachers teaching in big cities, in small cities and in towns. The table VI below shows the mean score of three groups of teachers' challenges in preparing Cambridge speaking test to young learners.

\section{Table VI:}

INDEPENDENT SAMPLE T TEST OF MEAN SCORE OF EFL TEACHERS' BY TEACHING AREAS

\begin{tabular}{lcccc}
\hline Variables & & Big cities & Small cities & Towns \\
\hline $\begin{array}{l}\text { EFL teachers' } \\
\text { challenges }\end{array}$ & $\mathbf{N}$ & 26 & 25 & 2 \\
& Mean & 2.98 & 3.07 & 2.62 \\
& SD & .38 & .05 & .34 \\
\hline
\end{tabular}

As showed in table VI, teachers teaching in small cities had the highest level of challenges $(M=3.07)$, followed by teachers teaching in big cities $(\mathrm{M}=2.98)$, while teachers teaching in towns faced challenges in the lowest degree $(M=2.62)$. The results indicated that there was no difference in the level of challenges in comparison among teachers teaching in big cities, small cities and towns $(\mathrm{t}=.-87, \mathrm{p}=.23, \mathrm{t}=2.01, \mathrm{p}=.37, \mathrm{t}=1.27, \mathrm{p}=.21)$. As a result, whatever areas teachers teaching in, their challenges in preparing Cambridge speaking tests to young learners are at high level.

All in all, as it can be concluded from the response of EFL teachers in some language centers, there are a lot of constraints in preparing Cambridge speaking tests to young learners. As EFL teachers indicated that the teaching methodology, time pressure, facilities and equipment, materials and resources, classroom context, teacher's level of English proficiency, learners' inhibition are the major constraints for teaching speaking in preparing Cambridge speaking tests to young learners. Noticeably, all EFL teachers at different degrees of teaching experience had the same challenges in preparing young learners for Cambridge speaking tests. In addition, female and male teachers 
DOI: $\underline{10.51386 / 25815946 / i j s m s-v 4 i 4 p 131}$

Volume: 4 Issue: 4

July to August 2021

https://www.ijsmsjournal.org

faced challenges at the same level. Moreover, whatever areas teachers teaching in, they also had lots of difficulties in preparing Cambridge speaking tests to young learners.

\section{DISCUSSION}

This study indicates that the participating teachers always face the challenges a lot during preparing Cambridge speaking tests to young learners. The following section discusses the findings from this study in relation to the research question.

As mentioned in the results, EFL teachers' challenges in preparing young learners for Cambridge speaking testsare categorized into seven types of them consisting of teaching methodology, time pressure, facilities and equipment, materials and resources, classroom context, teacher's level of English proficiency, learners' inhibition. Each category will be elaborated in this section by considering the way the teachers teach speaking in classroom. Particularly, EFL teachers faced the challenge of facilities and equipment most and teaching methodology leastin preparing young learners for Cambridge speaking tests.

The study confirms the findings from several studies in the literature (Copland, Garten and Burns, 2014). These authors indicate that EFL teachers really faced several difficulties in preparing Cambridge speaking tests to young learners. Overall, the findings on this research question support much previous research but the data also reveals that some challenges have not previously been identified such as facilities and equipment, learners' inhibition.

\section{CONCLUSIONS}

The findings add to the literature on challenges that EFL teachers face in preparing young learners for Cambridge speaking testsin language centers in the Mekong Delta, Vietnam. Based on the research results and the discussion, some conclusions are as follows.

Preparing Cambridge speaking tests to young learners is not easy for the teacher, so the understanding of the challenges will assist teachers in having a better view of applying effective strategies in training process and improve their teaching process to support their young learners' speaking skill development. EFL teachers has to teach them to communicate with speakers fluently. The language centers are able to establish an English community also to create opportunity for the children in improving their speaking ability. Then, the implementation of the teachers' strategies in preparing speaking process at training teaching methodology courses consist of strategy, lecturing, discussion, sharing.

There are a several of challenges that all EFL teachers faced in preparing young learners for Cambridge speaking tests. Partly by lack of facilities and equipment, partly by lack of teaching methodology and partly by lack of materials and resources. Especially, EFL teachers recognize that teaching methodology as a big challenge in Cambridge speaking tests preparation to young learners. Addressing classroom context is another challenge that could be met by EFL teachers a range of responses from training courses to book materials and it is certainly an issue that is both relevant and emergent. Other challenges are more localized, as the study reveal. These include teachers' level of English proficiency, and young learners' inhibition.

\section{About the Authors}

Ly HuongThi Nguyen is a teacher of English at a foreign language center in Vinh Long, Vietnam. She completed a bachelores degree of English in Education. She is currently an MA student at Can Tho University. Her research interest is teaching methodologies.

Mai Xuan Le is Head of Department of General English and English for Specific Purposes, School of Foreign Languages, CanTho University, Vietnam. Her research interests include English language teaching, ESP, curriculum 
development and teacher professional development. She is now involved in curriculum development and evaluation as well as supervising graduate and postgraduate students at the institution.

\section{REFERENCES}

[1] Brian C. Cronk. (2017). How to use SPSS. Tenth edition.

[2] British Council 2011 Brand and Design / B094 10 Spring Gardens. London SW1A 2BN, UK.

[3] Brown, H.D. 2004. Language Assessment Principles and Classroom Practices. New York: Pearson Education, Inc.

[4] Burns, A. \& Joyce, H. (1997). Focus on Speaking. Sydney: National center for English Language Teaching and Research.

[5] Cameron, L. (2001). Teaching Language to Young Learners. UK: Cambridge University Press.

[6] Copland, F. \&Garton, S. \&Burn, A. (2014). Investigating global practices in teaching English to young learners.

[7] Copland, F. \&Garton, S. \&Burn, A. (2014).Challenges in Teaching English to Young Learners: Global Perspectives and Local Realities.

[8] Gillham, B. (2008). Developing a questionnaire: A\&C Black.

[9] Halliwell, S., \&amp; Halliwell, S. (1992). Teaching English in the primary classroom. London: Longman.

[10] Le, T. M.(2019).An investigation into factors that hinder the participation of Univeristy students in English speaking lessons. IOSR Journal of Humanities and Social Science (IOSR-JHSS), 24(4), pp. 84-94.

[11] Likert, R. (1932). A Technique for the Measurement of Attitudes. Archives of Psychology, 140, 1-55.

[12] M.Sibarani. (2017). English Teachers'Strategies In Managing A Large Class At Smpn 4 Kota Jambi.

[13] Nashruddin,Wakhid. 2013.Understanding the Teaching of Listening and Speaking: Understanding Students' Needs. Malang: State University of Malang Press.

[14] Patton, M. Q. (2002). Research Methods and Qualitative Evaluation, (3rd ed.) CA: Sage.

[15] Rixon, Shelagh.1999. Young learners of English: some research perspectives. London: Longman.

[16] Ur, P. (2000). A Course in Language Teaching: Practice and Theory. Cambridge: Cambridge University Press.

[17] Uwe Flick. (2014).The SAGE Handbook of Qualitative Data Analysis.

[18] Zaremba, A. J. (2006). Speaking professionally. Canada: Thompson South-Western.

[19] http://www.cambridgeenglish.org/help

[20] http://dx.doi.org/10.1017/CBO9780511733109. 